\title{
The Effect of Aromatherapy on Work Stress in Sialang Rindang Village Office
}

\author{
Kursiah Warti Ningsih, Ambiyar, Muhammad Giatman, Emulyani, Dewi Permatasari
}

\begin{abstract}
Stress is an internal condition, can be caused by a physical (body), or environmental demands, and social situations, which are potentially damaging and uncontrolled. In a previous study, it had been carried out at the Sialang Rindang Village Office about work stress on 12 workers. Initial data obtained $33.3 \%$ or 4 people who experienced work stress from 12 respondents and $66.6 \%$ or 8 respondents did not experience work stress. To find out about the effect of giving aromatherapy to workers on work stress at the Sialang Rindang village office in 2020. The method used is a quantitative research using a quasi-experimental design. The number of samples used was 30 people. Before being given aromatherapy it is known that the average work stress score at the first measurement was 82.47 with a standard deviation of 33.277. After being given aromatherapy, it is known that the average work stress is 67.97 with a standard deviation of 13.389. Judging from the significant effect between the work stress of the first measurement with the second measurement, seen from the change in the mean value between the first and second measurements of 14.5 with a standard deviation of 19.8 where the statistical test results obtained $P$-value of $0,000(<0.05)$.
\end{abstract}

Keywords: work stress, aromatherapy, experiment.

\section{INTRODUCTION}

$\mathrm{O}$ ne of the pillars of success in occupational safety and health (K3) is the application of workplace ergonomics. Ergonomics is a component of K3 activities that optimally harmonize the work of the workforce to achieve work efficiency, effectiveness and comfort to increase work productivity. However, ergonomics problems in the industrial world are still not optimal. This is because many industries that still use machines in the work process still need human labour which has physical limitations in

Manuscript received on February 08, 2021.

Revised Manuscript received on March 30, 2021.

Manuscript published on March 30, 2021.

* Correspondence Author

Kursiah Warti Ningsih*, Doctoral Student of Technology and Vocational Education, Universitas Negeri Padang - Indonesia and Lecturer of the Study Program of Public Health, STIKes Payung Negeri Pekanbaru Indonesia. Email: kursiahwarti@gmail.com

Ambiyar, Senior lecturers/professors of Technology and Vocational Education, Universitas Negeri Padang - Indonesia: ambiyar@ft.unp.ac.id

Muhammad Giatman, Senior lecturers/professors of Technology and Vocational Education, Universitas Negeri Padang - Indonesia.: giatman@ft.unp.ac.id

Emulyani, Lecturer of the Study Program of Public Health, STIKes Payung Negeri Pekanbaru - Indonesia. Email: emulyani38@yahoo.co.id

Dewi Permatasari, Lecturer of the Study Program of Public Health, STIKes Payung Negeri Pekanbaru - Indonesia. Email: dedeepermata@gmail.com

(c) The Authors. Published by Blue Eyes Intelligence Engineering and Sciences Publication (BEIESP). This is an open access article under the CC BY-NC-ND license (http://creativecommons.org/licenses/by-nc-nd/4.0/) handling manual processes. This limitation causes risk factors for various occupational diseases [1]. Occupational diseases that often appear in workers' lack of maceration with their jobs are job stress. Stress is an internal condition, can be caused due to physical demands (body), or the environment, and social situations, which are potentially destructive and uncontrollable. To deal with work stress can make psychological and behavioural changes. Job stress occurs when due to a perceived imbalance between pressure and resources to cope with a particular situation.

Stress can be described in different ways from the level of stress, i.e 1) hypo-stress, too little stress or boredom can be a source of stress, pent up emotions, frustration, or apathy and depression; 2) eu-stress, at optimal pressure, the individual develops and maximizes performance. This is the side for stimulating stress, sometimes referred to as stress stimulation, which allows people to access hidden mental and physical abilities; 3) hyper-stress, excessive stress, hyper-stress individual experiences. At this stage, the person will feel out of control or panic and unable to cope; 4) distress - after prolonged stress. This individual may suffer from health problems and have a desire to get out of the situation and take a long rest [2].

According to a report from EU-OSHA, 51\% of workers report work-related stress is common in the workplace. The work stress in the Asia Pacific region exceeds the global average of around $48 \%$. Based on the results of the Regus survey in 2012, it was reported that the level of work stress in countries such as Malaysia reached 57\%, Hong Kong 62\%, Singapore $63 \%$, Vietnam $71 \%$, China $73 \%$, Indonesia $73 \%$, and Thailand $75 \%$. In Indonesia, it has increased by $9 \%$ from the previous year which was at the level of $64 \%$. The high percentage of work stress in Indonesia, apart from being influenced by domestic factors, is also related to individual and occupational factors [3].

Job stress is a part of modern life today, therefore there are several alternatives offered to deal with work stress, among others, stress management, which is a kind of training or employee assistance program to improve workers' ability to cope with difficult work situations. One thing that is being taught is how to use personal abilities to deal with work stress, for example with time management or relaxation exercises.

Another way to deal with work stress is with art therapy, through the movement tai chi or yoga, where both of them have almost the same healing process that is centred on breathing, body posture and body movements, but still has one goal, i.e changing the physical and emotional state for the better.

Published By:

Blue Eyes Intelligence Engineering

\& Sciences Publication

(C) Copyright: All rights reserved. 
From the many ways or therapies offered to deal with work stress, to the medical process that uses drugs, there is one way to deal with work stress which is an alternative treatment, i.e by giving aromatherapy. Aromatherapy is one of the herbal remedies using essential or aromatic oils obtained from plant distillation which aims to heal the body or emotional states [4].

From the results a preliminary survey that has been conducted at the Sialang Rindang Village Office regarding work stress on workers as many as 12 people. Initial data obtained $33.3 \%$ or 4 people who experienced work stress from the 12 respondents and $66.6 \%$ or 8 respondents did not experience work stress.

Based on the initial survey data above, work stress can be experienced by all workers, including workers in a village office. This is because the village office also has a system and hours of work and activities that can be said to be busy almost every day. Therefore, researchers conducted a study to determine the effect of giving aromatherapy to workers on work stress at the Sialang Rindang Village Office in 2020. Therefore, a method is used to reduce work stress on workers of the Sialang Rindang village office by providing aromatherapy.

\section{METHODS}

This type of research is a quantitative research using a quasi-experimental design, which is a study that applies experimental procedures but does not allow random

placement of subjects to conditions certain. In this study, the practical benefit is to see the effect of giving aromatherapy to workers on work stress at the Sialang Rindang Village Office in 2020. The location of this research is at the Sialang Rindang Village Office, Jl. Poros Sialang Rindang, Tambusai Sub-district, Rokan Hulu Regency. The time of the research was 4 days at the beginning of July 2020. The population is the whole object to be studied that has the same characteristics. The number of objects that will be taken by researchers is 30 workers at the Sialang Rindang Village Office. The research step in this experiment on the first day after obtaining research permission, the experimental object was given a questionnaire via google form before working. Then the object will be given aromatherapy at work for 4 days because the village office workers have never used an aromatherapy device, the researcher comes to the office to explain how to use it. Every day the researchers asked how the workers were doing after being given aromatherapy. The last day of the research, the researcher gave the same questionnaire after working through google form to measure work stress after being treated with aromatherapy for 4 consecutive days.

\section{RESULTS AND DISCUSSION}

\section{A. Univariate Analysis}

Table 1: Average value of work stress before given treatment therapy

\begin{tabular}{|c|c|c|c|}
\hline Variable & Mean Median & SD & Min - Max \\
\hline Work stress before being given aromatherapy & $\begin{array}{l}82.47 \\
66.00 \\
67.97\end{array}$ & 33.277 & $59-162$ \\
\hline Work stress after being given aromatherapy & 61.50 & 13,389 & $57-100$ \\
\hline
\end{tabular}

Source: Primary data 2020.

Based on Table 1, the average value of work stress before being treated using aromatherapy is a mean of 82.47 out of 30 respondents having a standard deviation of 33.277 with a minimum value of 59 and a maximum of 162 . For the average value of work stress after being given treatment using aromatherapy is a mean of 67.97 out of 30 respondents who have a standard deviation of 13.389 with a minimum value of 57 and a maximum of 100 .

\section{B. Bivariate Analysis}

Table 2: Effect of aromatherapy before and after working on workers on work stress

\begin{tabular}{|c|c|c|c|c|c|}
\hline Variable & Mean & SD & SE & P-value & $\mathbf{N}$ \\
\hline \multirow[t]{2}{*}{ Measurement I before being given aromatherapy } & 82.47 & 33.27 & & & \\
\hline & & & & 0.000 & 30 \\
\hline \multirow[t]{4}{*}{ Measurement II after being given aromatherapy } & 67.9 & & 7 & & \\
\hline & 13.389 & & & & \\
\hline & 6.076 & & & & \\
\hline & 2.445 & & & & \\
\hline
\end{tabular}

Source: Primary data 2020.

Based on the table above, are known to the average score of job stress on the first measurement is the mean of 82.47 with a standard deviation of 33.277. As for the second measurement, it is known that the average work stress is 67.97 with a standard deviation of 13.389 . It can be seen that the change in the mean value between the first and second measurements is 14.5 with a standard deviation of 19.8 . The statistical test results obtained P-value of $0.000(<0.05)$ and there is a significant influence between the work stress of the first measurement and the second measurement. It can be concluded that there is an effect of giving aromatherapy to workers on work stress at the Sialang Rindang Village Office in 2020 .

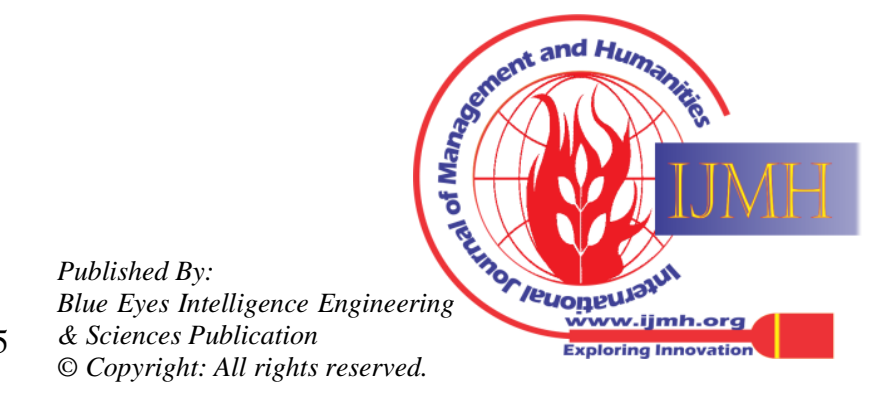




\section{Discussion}

Data analysis in this study was carried out univariately on 30 workers on work stress at the Sialang Rindang village office before being given aroma therapy, i.e mean 82 , 47 levels of work stress. After being given aromatherapy, that is, the mean level of work stress is 67.97.

According to [5] in general, stress is often interpreted as an unpleasant tense condition, because a person subjectively feels that something is burdening him or her. Employee job stress is a condition that arises from the interaction between humans and work and is characterized by human changes that force them to deviate from their normal functions.

The highest cause of stress is work which includes college assignments and works at the office. As many as 34\% of respondents stated that travelling can reduce stress and $13.4 \%$ of respondents used aromatherapy as relaxation to calm down. 57 respondents know about aromatherapy oil. It is stated that 55 of the 57 respondents like to use aromatherapy and 52 of them said that aromatherapy can affect the body and mind. The effects felt by 50 respondents included being able to calm the mind, be more relaxed, reduce stress, tension and insomnia [6-10].

In the bivariate analysis to determine whether there is a difference between the average values before and after giving therapy using aromatherapy. From the results of the Dependent T-test, it was found that the average score of work stress in the first measurement was 82.47 with a standard deviation of 33.277. After the second measurement, it is known that the average work stress is 67.97 with a standard deviation of 13.389. There is a very significant difference from the average value between the first measurement before and the second measurement after giving therapy with the second aromatherapy is 14.5 with a standard deviation of 19 , 8. Statistical test results obtained P-value of $0.000(<0.05)$. Based on the results of the statistical test, the alternative hypothesis (Ha) affects, aromatherapy affects workers in reducing work stress at the Sialang Rindang village office in 2020. [7] with the title "The Effect of Aroma Giving Lavender Therapy on Stress Levels in Undergoing Student's OSCE Sixth Semester Class VIII at STIKES Asaka Insan Banjarmasin "states that there is an effect of stress levels between before and after the intervention of aromatherapy technique methods is carried out on students. The responses experienced by students who have been given relaxation show various kinds, one of which is concentrating on the discussion, being energetic and not looking anxious or irritable.

The complex interactions between working conditions and the characteristics of workers that change normal physical and psychological functions, such as job demands that cannot be matched by workers' abilities as in the research results [7] show that there are changes stress levels after being given aromatherapy as well as the results of research conducted on village office workers showed a level of work stress. So that the researchers' assumptions of the results of this study indicate that before and after being given relaxation there is a very significant difference. This shows the effect of giving aromatherapy to workers on work stress at the Sialang Rindang village office in 2020.

\section{CONCLUSION}

From the results of the research that has been conducted on the effect of giving aromatherapy to workers on work stress at the Sialang Rindang village office in 2020, it can be concluded as follows i.e: the results of research on respondents before being given aromatherapy, it is known that the average score of work stress in the first measurement is 82.47 with a standard deviation of 33.277. From the results of research on respondents after being given aromatherapy, it is known that the average work stress is 67.97 with a standard deviation of 13.389. There is a reduction in work stress when compared to before being given aromatherapy. The effect of giving aromatherapy to workers on work stress at the Sialang Rindang Village Office in 2020. This can be seen from the significant influence between the first measurement work stress and the second measurement, seen from the change in the mean value between the first and second measurements of 14.5 with the standard deviation 19.8 where the statistical test results obtained $\mathrm{P}$-value of $0.000(<0.05)$.

\section{ACKNOWLEDGMENT}

The author gives endless thanks to God Almighty who has given gifts and opportunities in developing science. Thank you to all members of the Public Health Study Program of STIKes Payung Negeri Pekanbaru, as well as friends and students who have helped in this research activity. Do not forget to also thank the State Payung Foundation for facilitating this research activity and do not forget the author would like to thank the employees of the Sialang Rindang Village office who have been willing to become research respondents.

\section{REFERENCES}

1. I. M Ramdan, T. B. Laksmono. Determinan Keluhan Muskuloskeletal pada Tenaga Kerja Wanita Determinant of Musculosceletal Disorders Complaint on Female Workers. Jurnal Kesehatan Masyarakat Nasional, 2012, 7, pp. 169-172.

2. D.A. Kusumajati. Sumber-Sumber Stres Kerja. Humaniora, 1(45) 20107,pp. 92-800.

3. J. Habibi. Analisis Faktor Risiko Stres Kerja Pada Pekerja Di Unit Produksi Pt. Borneo Melintang Buana Export. Journal of Nursing and Public Health, 6(2), 2018, pp. 50-59.

4. N. Nidahyah, S. Rahmalia, V. Elita. Perbandingan Efektivitas Terapi Musik Klasik dengan Aromaterapi Mawar Terhadap Penderita Hipertensi. Jurnal Keperawatan Universitas Riau, 2(2), 2. 2015.

5. R. N. Massie, W.A. Areros. Pengaruh Stres Kerja Terhadap Kinerja Karyawan Pada Kantor Pengelola IT Center Manado. Jurnal Administrasi Bisnis, 6(002), 2018, pp. 41-49.

6. G. Ayu, P. Jyoti, P. Utami, P. Tjandrawibawa, U. Ciputra. Peran Aroma Terapi Melalui Media Lilin Sebagai Sarana Untuk Mengurangi Stres Pada Generasi Melenial. Kesehatan Masyarakat, 2020, pp. 188-195.

7. R. Melyanti. Aplikasi Pengelolaan Keberangkatan Penumpang pada PT. Indah Travel. Jurnal Ilmu Komputer, 7(1), 2018, pp 15-21.

8. R. Melyanti, M. Iqbal. Sistem Informasi Manajemen Penelitian Dan Pengabdian Masyarakat Di Bagian P3m (Studi Kasus: Stmik Hang Tuah Pekanbaru). Jurnal Ilmu Komputer, 9(2), 2020, pp. 165-176.

9. R. Melyanti R, Y. Andreas. Sistem E-wisata pada Dinas Pariwisata di Kota Pekanbaru Berbasis Android. Jurnal Ilmu Komputer, 6(2), 2017, pp. 124-127.

10. H. Hidayati, Suhardi, D. Irfan, A. Ambiyar, R. Melyanti. Sistem Informasi Pelanggaran Siswa Berbasis Web Menggunakan Rapid Application Development. INTECOMS: Journal of Information Technology and Computer Science, 3(2), 2020, pp. 234-242. 
11. Tricintia, Y. Ivana, T. Agustina, D. Pengaruh Pemberian Aroma Terapi Lavender Terhadap Tingkat Stress Dalam Menjalani OSCE Mahasiswa Semester VI Angkatan VIII Di STIKES Suaka Insan Banjarmasin. Kesehatan Masyarakat, 24. 2017

\section{AUTHORS PROFILE}

Dwi Sapta Aryantiningsih, is a Doctoral Student of Technology and Vocational Education, Universitas Negeri Padang - Indonesia and Lecturer of the Study Program of Public Health, STIKes Payung Negeri Pekanbaru - Indonesia.

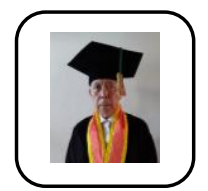

Ambiyar, is a Senior lecturers/professors of Technology and Vocational Education, Universitas Negeri Padang - Indonesia.

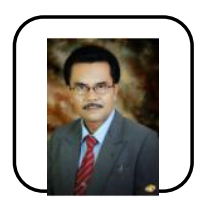

Muhammad Giatman, is a Senior lecturers/professors of Technology and Vocational Education, Universitas Negeri Padang - Indonesia.

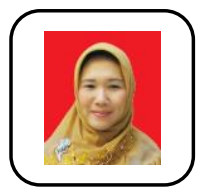

Emulyani, is a Lecturer of the Study Program of Public Health, STIKes Payung Negeri Pekanbaru Indonesia.

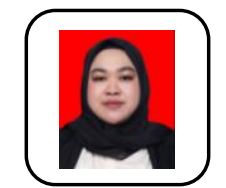

Dewi Permatasari, is a Lecturer of the Study Program of Public Health, STIKes Payung Negeri Pekanbaru - Indonesia.

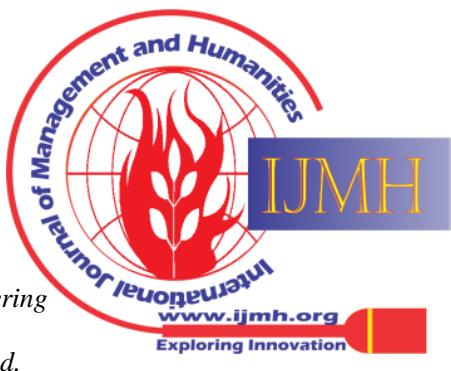

